medRxiv preprint doi: https://doi.org/10.1101/2022.02.10.22270706; this version posted February 10, 2022. The copyright holder for this preprint (which was not certified by peer review) is the author/funder, who has granted medRxiv a license to display the preprint in It is made available under a CC-BY-NC-ND 4.0 International license .

\title{
1 A scoping review protocol on in vivo human plastic exposure and health impacts
}

2

3 Louise M. Goodes ${ }^{1,2}$, Enoch V.S. Wong ${ }^{1}$, Jennifer Alex ${ }^{1}$, Louise Mofflin ${ }^{1}$, Priyanka

4 Toshniwal $^{1}$, Manuel Brunner ${ }^{1,3}$, Terena Solomons ${ }^{4}$, Emily White ${ }^{1}$, Omrik Choudhury ${ }^{1}$, Bhedita

5 J. Seewoo ${ }^{1,2}$, Yannick R. Mulders ${ }^{1}$, Tristan Dale ${ }^{1,5,6}$, Hamish J. Newman ${ }^{1,7,8}$, Andrew B. Lowe ,

6 Delia V. Hendrie ${ }^{10}$, Christos Symeonides ${ }^{1,11}$, Sarah A. Dunlop ${ }^{1,2}$

7

$8{ }^{1}$ Minderoo Foundation, 171 - 173 Mounts Bay Road, Perth, WA 6000, Australia

$9{ }^{2}$ School of Biological Sciences, The University of Western Australia, 35 Stirling Highway,

10 Crawley, WA 6009, Australia

$11{ }^{3}$ School of Molecular Sciences, The University of Western Australia, 35 Stirling Highway,

12 Crawley, WA 6009, Australia

$13{ }^{4}$ Health and Medical Sciences (Library), The University of Western Australia, 35 Stirling

14 Highway, Crawley, WA 6009, Australia

$15{ }^{5}$ Fiona Stanley Hospital, 11 Warren Drive, Murdoch, WA 6150, Australia

$16{ }^{6}$ UWA Medical School, Faculty of Health and Medical Sciences, The University of Western

17 Australia, 35 Stirling Highway, Crawley, WA 6009, Australia

$18{ }^{7}$ Sir Charles Gairdner Hospital, Hospital Ave, Nedlands, WA 6009, Australia

$19{ }^{8}$ School of Human Sciences, The University of Western Australia, 35 Stirling Highway,

20 Crawley, WA 6009, Australia

$21{ }^{9}$ School of Molecular \& Life Sciences, Curtin University, Kent St, Bentley WA 6102,

22 Australia

$23{ }^{10}$ School of Population Health, Curtin University, Kent St, Bentley WA 6102, Australia

$24{ }^{11}$ Murdoch Children's Research Institute, Royal Children's Hospital, 50 Flemington Rd, 25 Parkville, VIC 3052, Australia 
medRxiv preprint doi: https://doi.org/10.1101/2022.02.10.22270706; this version posted February 10, 2022. The copyright holder for this preprint (which was not certified by peer review) is the author/funder, who has granted medRxiv a license to display the preprint in It is made available under a CC-BY-NC-ND 4.0 International license .

ABSTRACT

27 Background: Global plastic production has increased exponentially since the 1960s, with more than 6300 million metric tons of plastic waste generated to date. Studies have found a range of human health impacts associated with exposure to plastic chemicals. However, only a fraction of plastic chemicals used have been studied in vivo, and then often in animals, for acute toxicological effects. With many questions still unanswered about how long-term exposure to plastic impacts human health, there is an urgent need to map human in vivo research conducted to date, casting a broad net by searching terms for a comprehensive suite of plastic chemical exposures and the widest range of health domains.

Methods: This protocol describes a scoping review that will follow the recommended framework outlined in 2017 Guidance for the Conduct of Joanna Briggs Institute (JBI) Scoping Reviews, to be reported in accordance with Preferred Reporting Items for Systematic Reviews and Meta-Analyses extension for Scoping Reviews (PRISMA-ScR) Checklist. A literature search of primary clinical studies in English from 1960 onwards will be conducted in MEDLINE (Ovid) and EMBASE (Ovid) databases. References eligible for inclusion will be identified through a quality-controlled, multi-level screening process. Extracted data will be presented in diagrammatic and tabular form, with a narrative summary addressing the review questions.

46 Discussion: This scoping review will comprehensively map the primary research undertaken to date on plastic exposure and human health. Secondary outputs will include extensive databases on plastic chemicals and human health outcomes/impacts.

50 Keywords: human, plastic, plastic chemicals, polymers, additives, exposure, health, toxicity 
medRxiv preprint doi: https://doi.org/10.1101/2022.02.10.22270706; this version posted February 10, 2022. The copyright holder for this preprint (which was not certified by peer review) is the author/funder, who has granted medRxiv a license to display the preprint in It is made available under a CC-BY-NC-ND 4.0 International license .

51

52 Registration: Open Science Framework (OSF)-Standard Pre-Data Collection Registration, https://osf.io/gbxps DOI: 10.17605/OSF.IO/GBXPS

54

55

BACKGROUND

56 Continuous human exposure to plastic chemicals has become inevitable due to its ubiquity in 57 the environment $(1,2)$. 'Plastic' is a broad term for material made up of polymers and usually a number of chemical additives that impart desirable properties, such as flexibility and fire resistance $(3,4)$. We will use the term 'plastic materials' as an umbrella term inclusive of plastic chemicals, plastic products and plastic particles; and 'plastic chemicals' to refer to polymers, monomers and/or additives.

62

As of 2017, approximately 8300 million metric tons (Mt) of virgin plastic chemicals had been produced, and as of 2015, 6300 million Mt of plastic waste generated (5). While some of the plastic waste is recycled or incinerated (5), the majority accumulates in landfills or in the environment (5), as macroplastic debris in the oceans (6-8), as microparticles in air (9-11), micro- or nanoparticles in soils (12-14) and in water supplies (15-18).

68

Plastic materials are used in every aspect of our lives (19) and common routes of exposure to plastic chemicals and particles (20) include inhalation (21), ingestion (including trophic transfer) (22-24), and direct dermal contact (25-27). Furthermore, children are exposed prenatally to plastic chemicals through maternal and paternal exposure (28), as well as postnatally through breast milk (29). 
medRxiv preprint doi: https://doi.org/10.1101/2022.02.10.22270706; this version posted February 10, 2022. The copyright holder for this preprint (which was not certified by peer review) is the author/funder, who has granted medRxiv a license to display the preprint in It is made available under a CC-BY-NC-ND 4.0 International license .

75 Of the thousands of plastic chemicals in use globally today, more than $20 \%$ have been

76 identified as substances of concern by the European Union on the basis of persistence,

77 bioaccumulation and/or toxicity, while 39\% remain unclassified in terms of hazard (30). Some

78 plastic chemicals are persistent organic pollutants that are known to bioaccumulate in human

79 fatty tissues (31). A growing body of evidence links human exposure to various plastic chemicals with adverse health impacts (32-35) and public concern about the threat of plastic pollution on our health is high (36). Despite this, research efforts have focused on a few plastic chemicals for which established measurement techniques exist (37) and for which a limited range of health impacts have been identified - primarily endocrine disruption (38-40), reproductive toxicity $(41,42)$, carcinogenicity $(43,44)$, metabolic and nutritional conditions (45), and neurodevelopment $(46,47)$. The findings of these studies are often inconsistent, as plastic chemical exposure can show sex-specific effects (38), differentially affect developmental stages (48), have health outcomes in association with specific plastic chemical mixtures (38), and can elicit non-monotonic responses (34). There is insufficient published data on the toxicity of micro- and nano-plastics in humans $(49,50)$, however an absence of evidence of toxicity does not equate to evidence of safety (51).

We are not aware of any sources or publications comprehensively summarising research conducted to date on how plastic chemicals and plastic particles are impacting human health, 94 or which populations, demographically and geographically, have been studied in this respect. 95 Preliminary searches conducted in Prospero, Epistimonikos, Cochrane, Medline (Ovid) and 96 Embase (Ovid) databases in May 2020 did not identify any previous or current scoping review on this broad topic. A number of systematic and literature reviews were identified, focusing on a small number of classes of plastic chemicals, such as phthalates, and bisphenol A (52-55), and certain diseases associated with these chemical species $(56,57)$. These systematic and 
medRxiv preprint doi: https://doi.org/10.1101/2022.02.10.22270706; this version posted February 10, 2022. The copyright holder for this preprint (which was not certified by peer review) is the author/funder, who has granted medRxiv a license to display the preprint in It is made available under a CC-BY-NC-ND 4.0 International license .

100 literature reviews addressed only a few specific chemicals and did not evaluate non disease-

101

103

104

105

106

107

108

109

110 To demonstrate the scope of research conducted to date, and to inform future research efforts, specific health domains, such as changes in gene expression, oxidative stress and the microbiome. Demographic and geographic bias (for example, due to social equity issues) were not evaluated, suggesting that many populations could be under-represented in the literature. For example, young children could be highly exposed and particularly vulnerable to the effects of some plastic chemicals $(53,58)$, and populations in developing countries could be at increased exposure risk (59) due to a combination of higher plastic pollution burden (60), combined with inadequate waste management facilities and lower occupational health and safety regulations (61). we will conduct a scoping review to chart published primary human in vivo studies that investigated the relationship between exposure to plastic materials and human health since 1960. The scoping review aims to summarise the research to date, identify knowledge gaps and provide a framework for future studies in areas requiring more in-depth research.

\section{Review question}

In primary human in vivo research conducted since 1960 on the effects of plastic materials on health, which plastic chemicals/particles and which health domains have (and have not) been investigated?

In relation to our main question, the following questions will inform sub-analyses:

1. Which populations (geographically, by age group, sex and general/special exposure risk status) have been examined?

2. Which study designs were adopted? 
medRxiv preprint doi: https://doi.org/10.1101/2022.02.10.22270706; this version posted February 10, 2022. The copyright holder for this preprint (which was not certified by peer review) is the author/funder, who has granted medRxiv a license to display the preprint in It is made available under a CC-BY-NC-ND 4.0 International license .

3. When were these studies conducted over time (Jan 1960-Jan 2021)?

126

\section{Inclusion and exclusion criteria}

128 The Population, Exposure and Outcome (PEO) mnemonic (Table 1) was created to construct 129 clear inclusion criteria

130

131 Table 1: PEO framework for identifying the research question and inclusion criteria.

\section{Criteria Determinants}

Population Global human populations of all ages, including the developing fetus

Exposure Directly in vivo measured exposures to included plastic materials

Outcome Direct in vivo physiological or psychological health outcome measures

132

133 Population

134 The review will consider studies that investigate any population globally, and any age group,

135 including the developing fetus. Animal studies and in vitro human studies will be excluded.

137 Exposure

138 Only in vivo directly measured exposures (i.e. via bio-samples, including for example blood,

139 urine, breast milk and adipose tissue) of plastic materials that meet inclusion criteria will be

140 included. All avenues of plastics exposure are considered relevant, including environmental 141 contact via activities of everyday living, occupational exposure, accidental ingestion through

142 contaminated food or water, cross-placental exposure, and ingestion through breast milk. 
medRxiv preprint doi: https://doi.org/10.1101/2022.02.10.22270706; this version posted February 10, 2022. The copyright holder for this preprint (which was not certified by peer review) is the author/funder, who has granted medRxiv a license to display the preprint in

It is made available under a CC-BY-NC-ND 4.0 International license .

\section{Plastics inclusion and exclusion criteria}

145 This scoping review focuses on plastic materials to which humans are generally exposed, other

146 than at the point of synthesis or product manufacturing. A systematic decision-making process

147 (Figure 1) will be applied to determine the inclusion or exclusion of plastic chemicals. Briefly,

148 plastic additives and synthetic polymers will be identified from preselected references: seven

149 for additives (62-68), and seven for polymers (69-75). Chemicals that are classified as additive

150 - plasticiser, additive - flame retardant, per- and polyfluoroalkyl substances (PFAS),

151 individual polymer or polymer class and bisphenols will be included, unless commonly used

152 in biomedical applications or as food additives (since inclusion would result in the retrieval of

153 many thousands of references unrelated to the effects of plastic chemicals on health).

154 Additional plastic chemicals identified during the screening process, or missing plastic

155 chemicals that are structurally and systematically related to included substances (based on

156 expert decision by Authors JA and MB, postdoctoral degrees in chemistry), will undergo the

157 same selection criteria and subsequently included or excluded. Polymer metabolites,

158 monomers other than bisphenols, and plastic additives other than plasticisers and flame

159 retardants, are excluded from this review.

160

161 A comprehensive and searchable database of included plastic chemicals will be developed,

162 indexing the multiple names, synonyms and commonly used terminology describing these

163 chemicals.

\section{Outcome}

166 Only physiological and psychological changes in human health that are directly measured in

167 vivo are included. 
medRxiv preprint doi: https://doi.org/10.1101/2022.02.10.22270706; this version posted February 10, 2022. The copyright holder for this preprint (which was not certified by peer review) is the author/funder, who has granted medRxiv a license to display the preprint in

It is made available under a CC-BY-NC-ND 4.0 International license.

169

170 Health outcome measures include any assessment of change in structure or function of the

171 human body, whether undertaken at the clinical, functional, physiological or cellular level.

172 From preliminary searches, we anticipate encountering three types of health-related impact

173 assessments in relation to plastics exposures:

174

175

176

177

178

179

180

181

183

184

185

186

187

188

189

190

191

192

193

1. Measures of direct impact on human health as a diagnosis of illness or disease, for example, breast cancer;

2. Clinical measures to detect a disease/disorder where no illness/disease has been diagnosed, for example oestrogen levels as a measure of change in ovarian function; and

3. Measures of impact on physiological or biochemical measures within an organ/body system that are not associated with a specific disorder, for example genetic and epigenetic changes and measures of metabolism and oxidative stress.

We will include measures of all the health-related impacts listed above, classifying them within the body system/organ in which they were investigated, using the hierarchical structure of the International Classification of Disease $11^{\text {th }}$ Revision (ICD-11) (76).

\section{Types of sources}

This scoping review considers peer-reviewed journal articles presenting primary human research, inclusive of all study designs. Excluded sources are literature/systematic reviews, meta-analyses, editorials, book reviews/chapters, perspectives, opinion/commentary pieces, conference abstracts and proceedings, and grey literature. 
medRxiv preprint doi: https://doi.org/10.1101/2022.02.10.22270706; this version posted February 10, 2022. The copyright holder for this preprint (which was not certified by peer review) is the author/funder, who has granted medRxiv a license to display the preprint in It is made available under a CC-BY-NC-ND 4.0 International license.

\section{METHODS}

195

196

Design

197 The scoping review uses the methodological framework as described in the Updated 198 methodological guidance for the conduct of scoping reviews (77) and reporting will be 199 compliant with the Preferred reporting items for systematic reviews and meta-analyses extension for scoping reviews (PRISMA-ScR) Checklist (78) (see Additional file I for completed PRISMA-P checklist accompanying this Protocol) and informed by Conducting high quality scoping reviews - challenges and solutions (79).

Constructing the search strategy

205

The search strategy aims to find published plastic chemicals/particles and human health studies from 1960 onwards. The starting point of 1960 was selected since, although large-scale use of plastic dates back to $\sim 1950$, significant increases in global production occurred from the 1960s onward (5).

We identified key articles relevant for our scoping review by conducting an initial scoping search in Medline (Ovid) and Embase (Ovid) databases and examining the hierarchy of controlled vocabulary in these databases (MeSH and Emtree respectively). Indexed terms were 213 selected representing plastic materials (including commonly used terms for chemical classes meeting our inclusion criteria) and a broad range of health outcome categories informed by preliminary searches and expert input from Author CS, a consultant paediatrician with relevant research expertise (most human health categories being represented, except for those obviously

217 unrelated to plastic chemical exposure or likely to result in the retrieval of many irrelevant 218 results). MeSH and Emtree terms, corresponding text words, text words contained in the titles 
medRxiv preprint doi: https://doi.org/10.1101/2022.02.10.22270706; this version posted February 10, 2022. The copyright holder for this preprint (which was not certified by peer review) is the author/funder, who has granted medRxiv a license to display the preprint in It is made available under a CC-BY-NC-ND 4.0 International license .

and abstracts of key articles, and terms and synonyms for all specific plastic chemicals included in our database, will comprise the final search strategy, being developed in consultation with

221 Research Librarian, Author TS. A large number of exclusion terms such as "plastic surgery", 222 plasticity, etc., will be utilised to minimise irrelevant results.

224 In summary, the search strategy will include: Health outcomes AND plastic material exposures NOT exclusions, limited to English language and dates ranging from 1960 to current. A search human-only studies and exclude animal studies (80-82). The keywords and indexed terms representing health outcomes will be combined with Boolean operator OR and combined using the Boolean Operator AND with the keywords and indexed terms for plastic materials. The proximity operator ADJ will capture terms adjacent within a tested number of words within the title and abstract fields, and the truncation symbol * will be used where appropriate.

233 Scopus and Web of Science databases were investigated as sources, however due to the lack of controlled vocabulary and no filters for human-only studies, these will not be searched.

In anticipation of a very large number of results from this search, the reference lists of retrieved papers will not be reviewed. We will, however, review the reference lists associated with a 238 related 'Umbrella Review' of systematic reviews with meta-analyses on this topic, being conducted by Minderoo Foundation and reported separately (in preparation).

241 Study selection

242 All identified articles will be collated and uploaded into the DistillerSR (Evidence Partners,

243 Ottawa, Canada) systematic review software application for screening and data extraction, and 
medRxiv preprint doi: https://doi.org/10.1101/2022.02.10.22270706; this version posted February 10, 2022. The copyright holder for this preprint (which was not certified by peer review) is the author/funder, who has granted medRxiv a license to display the preprint in It is made available under a CC-BY-NC-ND 4.0 International license .

244 deduplicated. Relevant articles will then be selected via two screening stages, each preceded

245 by an in-depth training process for the team of reviewers, who have postgraduate and

246 postdoctoral degrees in chemistry, biochemistry, environmental and health sciences. Training

247 will involve the provision of guidelines, including inclusion/exclusion criteria and practical

248 examples of their application, education on classifying study design, access to our database of

249 included plastic chemicals and demonstration of the screening process using relevant articles

250 to be included for the scoping review, ensuring consistency and reliability of assessment

251 decisions.

252

253 References will first be screened for relevance by title, abstract and index terms. Reviewers will initially screen several sets of the same 100 references and discuss their screening decisions, proceeding to single-screening after achieving an $85 \%$ level of agreement with subsequently agreed (resolved) group decisions over three sets. Articles with no abstract but potentially relevant to the scoping review will be included at the first screening stage. Auditing will be performed on a random selection of screened references to evaluate screening accuracy, and we will use the inbuilt artificial intelligence (DistillerAI) tool to identify possible false exclusions, re-screening references as necessary and thereby minimising the number of valuable articles being discarded.

263 During the second screening stage, full-text articles will be reviewed for eligibility. Training 264 will again involve the screening of several sets of full-texts, with discussions after each set about screening decisions. Reviewers will proceed to single-screening only after achieving an $85 \%$ level of agreement with subsequently resolved group decisions and excluding no more than two eligible articles in error per 100 full-texts. Eligible articles will be included for data 
medRxiv preprint doi: https://doi.org/10.1101/2022.02.10.22270706; this version posted February 10, 2022. The copyright holder for this preprint (which was not certified by peer review) is the author/funder, who has granted medRxiv a license to display the preprint in It is made available under a CC-BY-NC-ND 4.0 International license .

extraction, whereas articles excluded once will require a second reviewer to confirm the exclusion. Any disagreements will be resolved by a third reviewer with relevant experience.

\section{DATA EXTRACTION}

The data to be extracted will include specific publication details, study characteristics, relevant plastic exposures detected in the body and the health outcome measures analysed in relation to plastic exposures. Data extraction forms designed in DistillerSR (drafts are provided in Additional file II) will be piloted extensively during a period of training, involving independent reviewing followed by group meetings to discuss decisions and revise forms as necessary (final versions to be provided in the scoping review paper). Two reviewers will extract data from each full-text. Reviewer pairs will discuss conflicts that arise, with input from a third reviewer with the most relevant expertise if assistance is required to resolve decisions. Articles may be excluded during this phase if found ineligible or if it is impossible to extract data due to ambiguity or poor reporting quality, with the reasons for exclusion reported in the final paper.

The findings reported in the included studies, i.e. correlations between plastic exposures and health outcome measures, or lack thereof, will not be recorded, since we are following the typical scoping review framework, without conducting quality assessment of retrieved articles. The afore-mentioned 'Umbrella Review' of systematic reviews with meta-analyses will capture high-level evidence on this topic.

\section{DATA ANALYSIS AND PRESENTATION}

Frequency counts and descriptive statistics will be presented for publication details and study characteristics. The extracted data will be presented graphically, in diagrammatic and tabular 
medRxiv preprint doi: https://doi.org/10.1101/2022.02.10.22270706; this version posted February 10, 2022. The copyright holder for this preprint (which was not certified by peer review) is the author/funder, who has granted medRxiv a license to display the preprint in It is made available under a CC-BY-NC-ND 4.0 International license .

form, in a manner that aligns with the objective of this scoping review. A narrative summary will accompany the tabulated and charted results.

294

295 Graphical illustrations will show the trend, by year of publication, for when studies about the

296 impact of plastics and health were conducted; the number of articles by country of authors and investigated study populations; age ranges and sex of participants; frequency of the different study designs used; the plastic chemical/particle exposures and health outcome measures. The results will be presented to address the research questions, make comparisons, identify methodologies used and identify research gaps.

\section{DISCUSSION}

303 This scoping review aims to provide a comprehensive overview of research published since

3041960 on the exposure of humans to plastic materials and the health outcomes assessed. Due to 305 the breadth of our review question, we anticipate a large number of studies to intersect with the 306 PEO framework. A detailed search strategy has been designed to identify eligible studies based on all three criteria: in vivo human populations, directly measured plastic materials that are included according to clear criteria and scientifically reliable sources, and direct measures of human health outcomes.

311 While health outcomes traditionally involve diseases and health conditions, the potential 312 impacts of plastic materials may be subtle, perhaps only becoming apparent over time. By 313 adapting the ICD-11 sub-categories to include health outcomes not necessarily classified as

314 disease states (e.g. epigenetic changes and oxidative stress measures), this scoping review aims 315 to identify a wider suite of health-related outcome measures that should be taken into 
medRxiv preprint doi: https://doi.org/10.1101/2022.02.10.22270706; this version posted February 10, 2022. The copyright holder for this preprint (which was not certified by peer review) is the author/funder, who has granted medRxiv a license to display the preprint in It is made available under a CC-BY-NC-ND 4.0 International license.

consideration for plastic exposure research. This database could also benefit future research

317 endeavours.

318

319 In summary, this scoping review will provide an overview of the research so far undertaken on

320 plastic material exposure and human health. This can serve as a basis to identify research clusters, by topic and geographical location of studied populations, as well as knowledge gaps, helping to prioritise specific areas in need of more in-depth research. Additionally, alongside

323 the primary outputs, findings may be used to strengthen efforts to better regulate the production,

324 importation and use of plastic materials that human populations are ubiquitously exposed to.

326 Additional (Supplementary) Information

327 Additional file I: Completed PRISMA-P checklist (PDF)

328 Additional file II: Draft data extraction forms (PDF)

329

330 Figure Titles

331 Figure 1: Schematic overview of the process for inclusion/exclusion of plastic chemicals in

332 the scoping review

333 Figure 2: Study selection process

335 Abbreviations

336 ICD-11: International Classification of Disease $11^{\text {th }}$ Revision

337 JBI: Joanna Briggs Institute

338 OSF: Open Science Framework

339 PEO: Population, Exposure and Outcome 
medRxiv preprint doi: https://doi.org/10.1101/2022.02.10.22270706; this version posted February 10, 2022. The copyright holder for this preprint (which was not certified by peer review) is the author/funder, who has granted medRxiv a license to display the preprint in It is made available under a CC-BY-NC-ND 4.0 International license.

PRISMA-ScR: Preferred reporting items for systematic reviews and meta-analyses extension for scoping reviews

342

\section{Definitions}

344 plastic chemicals: polymers, monomers and/or additives

345 plastic materials: plastic chemicals, plastic products and plastic particles

\section{Acknowledgements}

348 The selection of specific plastic materials and associated terms was determined in consultation

349 with polymer science expert Dr Marck Norret, The University of Western Australia. We also 350 acknowledge the contribution from Brady Johnston, Minderoo Foundation, to create searchable online databases of our included plastics and health outcome measures, using the "Shiny" package in RStudio; and from Meredith Ryland and Joanne Webb, Minderoo Foundation, towards the writing of this manuscript.

\section{Authors' contributions}

356 Scoping review design: Sarah A. Dunlop, Christos Symeonides, Louise M. Goodes, Delia

357 Hendrie, Tristan Dale, Hamish Newman, Enoch V.S. Wong, Priyanka Toshniwal

358 Manuscript: Louise Goodes, Enoch V.S. Wong, Louise Mofflin, Priyanka Toshniwal,

359 Manuel Brunner, Terena Solomons, Yannick Mulders, Sarah A. Dunlop (guarantor)

360 Review of Manuscript: Christos Symeonides, Jennifer Alex, Tristan Dale, Hamish Newman,

361 Andrew Lowe, Delia Hendrie

362 Identification of plastics and their sources: Emily White, Jennifer Alex, Christos Symeonides, 363 Andrew Lowe 
medRxiv preprint doi: https://doi.org/10.1101/2022.02.10.22270706; this version posted February 10, 2022. The copyright holder for this preprint (which was not certified by peer review) is the author/funder, who has granted medRxiv a license to display the preprint in It is made available under a CC-BY-NC-ND 4.0 International license.

Classification of study designs, health outcomes and measures: Bhedita Seewoo, Christos

Funding

369 This scoping review was supported by Minderoo Foundation.

370

\section{Availability of data and materials}

372 All data generated or analysed will be included in the final published scoping review article and additional information related to the protocol will be available upon reasonable request.

\section{Ethics approval and consent to participate}

376 Formal research ethics approval is not required for scoping review the published literature. The

377 findings of the scoping review will be disseminated via Minderoo Foundation website, peer378 reviewed scientific publication, presented at congresses or conferences, to policy makers and stakeholders aiming to achieve a world free of plastic pollution, and through various social media platforms. Data deposition and curation will be managed by Minderoo Foundation.

\section{Consent for publication}

383 Not applicable.

\section{Competing interests}

386 The authors declare they have no competing interests and they have developed this protocol 387 without input from any funding body. 
medRxiv preprint doi: https://doi.org/10.1101/2022.02.10.22270706; this version posted February 10, 2022. The copyright holder for this preprint (which was not certified by peer review) is the author/funder, who has granted medRxiv a license to display the preprint in It is made available under a CC-BY-NC-ND 4.0 International license .

\section{REFERENCES}

391 1. Landrigan PJ, Stegeman JJ, Fleming LE, Allemand D, Anderson DM, Backer LC, et 392 al. Human health and ocean pollution. Ann Glob Health. 2020 Dec 3;86(1):1-64.

393 2. Bergmann M, Mützel S, Primpke S, Tekman MB, Trachsel J, Gerdts G. White and 394 wonderful? Microplastics prevail in snow from the Alps to the Arctic. Sci Adv. 2019 Aug $39514 ; 5(8)$.

396 3. Directive (EU) 2019/904. The reduction of the impact of certain plastic products on 397 the environment. Off J Eur Union Eur Parliam Counc. L 155/1:1-19.

398 4. Fahlman BD. Polymeric Materials. Mater Chem. 2018;373-483.

$3995 . \quad$ Geyer R, Jambeck JR, Law KL. Production, use, and fate of all plastics ever made. $400 \quad$ Sci Adv. 2017 Jul 5;3(7):e1700782.

401 6. Cózar A, Echevarría F, González-Gordillo JI, Irigoien X, Úbeda B, Hernández-León 402 S, et al. Plastic debris in the open ocean. Proc Natl Acad Sci U S A. 2014 Jul $403 \quad 15 ; 111(28): 10239-44$.

$4047 . \quad$ Van Der Mheen M, Van Sebille E, Pattiaratchi C. Beaching patterns of plastic debris 405 along the Indian Ocean rim. Ocean Sci. 2020 Oct 30;16(5):1317-36.

406 8. Jang YC, Lee J, Hong S, Lee JS, Shim WJ, Song YK. Sources of plastic marine 407 debris on beaches of Korea: More from the ocean than the land. Ocean Sci J. 2014 Jul $408 \quad 6 ; 49(2): 151-62$.

409 9. Liao Z, Ji X, Ma Y, Lv B, Huang W, Zhu X, et al. Airborne microplastics in indoor 410 and outdoor environments of a coastal city in Eastern China. J Hazard Mater. 2021 Sep $5 ; 417: 126007$. 
medRxiv preprint doi: https://doi.org/10.1101/2022.02.10.22270706; this version posted February 10, 2022. The copyright holder for this preprint (which was not certified by peer review) is the author/funder, who has granted medRxiv a license to display the preprint in It is made available under a CC-BY-NC-ND 4.0 International license .

412

413

414

415

416

417

418

419

420

421

422

423

424

425

426

427

428

429

430

431

432

433

434

435

10. Dris R, Gasperi J, Saad M, Mirande C, Tassin B. Synthetic fibers in atmospheric fallout: A source of microplastics in the environment? Mar Pollut Bull. 2016 Mar 15;104(12):290-3

11. Wesch C, Elert AM, Wörner M, Braun U, Klein R, Paulus M. Assuring quality in microplastic monitoring: About the value of clean-air devices as essentials for verified data. Sci Rep. 2017 Dec 1;7(1):1-8.

12. Scheurer M, Bigalke M. Microplastics in Swiss Floodplain Soils. Environ Sci Technol. 2018 Mar 20;52(6):3591-8.

13. He P, Chen L, Shao L, Zhang H, Lü F. Municipal solid waste (MSW)landfill: A source of microplastics? -Evidence of microplastics in landfill leachate. Water Res. 2019 Aug $1 ; 159: 38-45$.

14. Wahl A, Le Juge C, Davranche M, El Hadri H, Grassl B, Reynaud S, et al. Nanoplastic occurrence in a soil amended with plastic debris. Chemosphere. 2021 Jan $1 ; 262: 127784$.

15. Pivokonsky M, Cermakova L, Novotna K, Peer P, Cajthaml T, Janda V. Occurrence of microplastics in raw and treated drinking water. Sci Total Environ. 2018 Dec 1;643:164451.

16. Mintenig SM, Löder MGJ, Primpke S, Gerdts G. Low numbers of microplastics detected in drinking water from ground water sources. Sci Total Environ. 2019 Jan $15 ; 648: 631-5$.

17. Kosuth M, Mason SA, Wattenberg E V. Anthropogenic contamination of tap water, beer, and sea salt. PLoS ONE. 2018 Apr 1;13(4):e0194970.

18. Lai Y, Dong L, Li Q, Li P, Hao Z, Yu S, et al. Counting Nanoplastics in Environmental Waters by Single Particle Inductively Coupled Plasma Mass Spectroscopy 
medRxiv preprint doi: https://doi.org/10.1101/2022.02.10.22270706; this version posted February 10, 2022. The copyright holder for this preprint (which was not certified by peer review) is the author/funder, who has granted medRxiv a license to display the preprint in It is made available under a CC-BY-NC-ND 4.0 International license .

436

437

438

439

440

441

442

443

444

445

446

447

448

449

450

451

452

453

454

455

456

457

458

459

after Cloud-Point Extraction and in Situ Labeling of Gold Nanoparticles. Environ Sci Technol. 2021 Apr 20;55(8):4783-91.

19. de Sousa FDB. The role of plastic concerning the sustainable development goals: The literature point of view. Clean Responsible Consum. 2021 Dec 1;3:100020.

20. Enyoh CE, Shafea L, Verla AW, Verla EN, Qingyue W, Chowdhury T, et al.

Microplastics exposure routes and toxicity studies to ecosystems: An overview. Vol. 35, Environmental Health and Toxicology. Korean Society of Environmental Health and Toxicology; 2020.

21. Pauly JL, Stegmeier SJ, Allaart HA, Cheney RT, Zhang PJ, Mayer AG, et al. Inhaled cellulosic and plastic fibers found in human lung tissue. Cancer Epidemiol Biomarkers Prev. 1998 May 1;7(5):419-28.

22. Dar E, Kanarek MS, Anderson HA, Sonzogni WC. Fish consumption and reproductive outcomes in Green Bay, Wisconsin. Environ Res. 1992 Oct 1;59(1):189-201.

23. Anderson HA, Wolff MS, Lilis R, Holstein EC, Valciukas JA, Anderson KE, et al. Symptoms and clinical abnormalities following ingestion of polybrominated-biphenylcontaminated food products. Ann N Y Acad Sci. 1979;320(1):684-702.

24. Jamieson DJ, Terrell ML, Aguocha NN, Small CM, Cameron LL, Marcus M. Dietary exposure to brominated flame retardants and abnormal pap test results. $J$ Womens Health. 2011 Sep 1;20(9):1269-78.

25. Lv Y, Lu S, Dai Y, Rui C, Wang Y, Zhou Y, et al. Higher dermal exposure of cashiers to BPA and its association with DNA oxidative damage. Environ Int. 2017 Jan 1;98:69-74.

26. Lazarov A, Cordoba M. Purpuric contact dermatitis in patients with allergic reaction to textile dyes and resins. J Eur Acad Dermatol Venereol. 2000;14(2):101-5. 
medRxiv preprint doi: https://doi.org/10.1101/2022.02.10.22270706; this version posted February 10, 2022. The copyright holder for this preprint (which was not certified by peer review) is the author/funder, who has granted medRxiv a license to display the preprint in It is made available under a CC-BY-NC-ND 4.0 International license .

460 27. Majasuo S, Liippo J, Lammintausta K. Non-occupational contact sensitization to 461 epoxy resin of bisphenol A among general dermatology patients. Contact Dermatitis. 2012 Mar;66(3):148-53.

463 28. Breton CV, Landon R, Kahn LG, Enlow MB, Peterson AK, Bastain T, et al.

464 Exploring the evidence for epigenetic regulation of environmental influences on child health

465

466

467

468

469

470

471

472

473

474

475

476

477

478

479

480

481

482

483

484 across generations. Commun Biol. 2021 Jun 22;4(1):1-15.

29. Chao H-R, Wang S-L, Lee W-J, Wang Y-F, Päpke O. Levels of polybrominated diphenyl ethers (PBDEs) in breast milk from central Taiwan and their relation to infant birth outcome and maternal menstruation effects. Environ Int. 2007 Feb 1;33(2):239-45.

30. Wiesinger H, Wang Z, Hellweg S. Deep Dive into Plastic Monomers, Additives, and Processing Aids. Environ Sci Technol. 2021 Jul 6;55(13):9339-51.

31. Jackson E, Shoemaker R, Larian N, Cassis L. Adipose Tissue as a Site of Toxin Accumulation. Compr Physiol. 2017 Oct 1;7(4):1085-135.

32. Lithner D, Larsson A, Dave G. Environmental and health hazard ranking and assessment of plastic polymers based on chemical composition. Sci Total Environ. 2011 Aug 15;409(18):3309-24.

33. Demeneix BA. Evidence for Prenatal Exposure to Thyroid Disruptors and Adverse Effects on Brain Development. Eur Thyroid J. 2019 Dec 1;8(6):283-92.

34. Vandenberg L, Colborn T, Hayes T, Heindel J, Jacobs D, Lee D, et al. Hormones and endocrine-disrupting chemicals: low-dose effects and nonmonotonic dose responses. Endocr Rev. 2012 Jun;33(3):378-455.

35. Vethaak AD, Legler J. Microplastics and human health. Science. 2021;371(6530):672-4.

36. Davison SMC, White MP, Pahl S, Taylor T, Fielding K, Roberts BR, et al. Public concern about, and desire for research into, the human health effects of marine plastic 
medRxiv preprint doi: https://doi.org/10.1101/2022.02.10.22270706; this version posted February 10, 2022. The copyright holder for this preprint (which was not certified by peer review) is the author/funder, who has granted medRxiv a license to display the preprint in It is made available under a CC-BY-NC-ND 4.0 International license .

485

486

487

488

489

490

491

492

493

494

495

496

497

498

499

500

501

502

503

504

505

506

507

pollution: Results from a 15-country survey across Europe and Australia. Glob Environ Change. 2021 Jun 17;102309.

37. Manini P, Andreoli R, Niessen W. Liquid chromatography-mass spectrometry in occupational toxicology: a novel approach to the study of biotransformation of industrial chemicals. J Chromatogr A. 2004 Nov 26;1058(1-2):21-37.

38. Tanner EM, Hallerbäck MU, Wikström S, Lindh C, Kiviranta H, Gennings C, et al. Early prenatal exposure to suspected endocrine disruptor mixtures is associated with lower IQ at age seven. Environ Int. 2020 Jan 1;134:105185.

39. Fu X, Xu J, Zhang R, Yu J. The association between environmental endocrine disruptors and cardiovascular diseases: A systematic review and meta-analysis. Environ Res. 2020 Aug 1;187:109464.

40. Gore AC, Chappell VA, Fenton SE, Flaws JA, Nadal A, Prins GS, et al. EDC-2: The Endocrine Society's Second Scientific Statement on Endocrine-Disrupting Chemicals. Endocr Rev. 2015 Dec 1;36(6):E1-150.

41. Cai H, Zheng W, Zheng P, Wang S, Tan H, He G, et al. Human urinary/seminal phthalates or their metabolite levels and semen quality: A meta-analysis. Environ Res. 2015 Oct 1;142:486-94.

42. Golestanzadeh M, Riahi R, Kelishadi R. Association of phthalate exposure with precocious and delayed pubertal timing in girls and boys: a systematic review and metaanalysis. Environ Sci Process Impacts. 2020 Apr 29;22(4):873-94.

43. Boffetta P, Catalani S, Tomasi C, Pira E, Apostoli P. Occupational exposure to polychlorinated biphenyls and risk of cutaneous melanoma: A meta-analysis. Eur J Cancer Prev. 2018 Jan 1;27(1):62-9. 
medRxiv preprint doi: https://doi.org/10.1101/2022.02.10.22270706; this version posted February 10, 2022. The copyright holder for this preprint (which was not certified by peer review) is the author/funder, who has granted medRxiv a license to display the preprint in It is made available under a CC-BY-NC-ND 4.0 International license .

508

509

510

511

512

513

514

515

516

517

518

519

520

521

522

523

524

525

526

527

528

529

530

531

532

44. Zhang K, Shi H, Peng J, Wang Y, Xiong X, Wu C, et al. Microplastic pollution in China's inland water systems: A review of findings, methods, characteristics, effects, and management. Sci Total Environ. 2018 Jul 15;630:1641-53.

45. Kim KY, Lee E, Kim Y. The Association between Bisphenol A Exposure and Obesity in Children-A Systematic Review with Meta-Analysis. Int J Environ Res Public Health. 2019 Jul 15;16(14):E2521.

46. Lam J, Lanphear BP, Bellinger D, Axelrad DA, McPartland J, Sutton P, et al.

Developmental pbde exposure and IQ/ADHD in childhood: A systematic review and metaanalysis. Environ Health Perspect. 2017 Aug 1;125(8).

47. Radke EG, Braun JM, Nachman RM, Cooper GS. Phthalate exposure and neurodevelopment: A systematic review and meta-analysis of human epidemiological evidence. Environ Int. 2020 Apr 1;137:105408.

48. Braun JM. Early-life exposure to EDCs: role in childhood obesity and neurodevelopment. Nat Rev Endocrinol 2016 133. 2016 Nov 18;13(3):161-73.

49. SAPEA A. Scientific Perspective on Microplastics in Nature and Society. Sci Advice Policy Eur Acad Berl. 2019;

50. World Health Organization. Microplastics in drinking-water [Internet]. 2019 p. 1101. Report No.: 9789241516198 . Available from:

https://apps.who.int/iris/handle/10665/326499

51. Leslie HA, Depledge MH. Where is the evidence that human exposure to microplastics is safe? Environ Int. 2020 Sep 1;142:105807.

52. Gómez-Mercado CA, Mejía-Sandoval G, Segura-Cardona ÁM, Arango-Alzate CM, Hernández-González SI, Patiño-García DF, et al. Exposición a Bisfenol A (BPA) en mujeres embarazadas y su relación con la obesidad en sus hijos: revisión sistemática. Rev Fac Nac Salud Pública. 2018 Mar 31;36(1):66-74. 
medRxiv preprint doi: https://doi.org/10.1101/2022.02.10.22270706; this version posted February 10, 2022. The copyright holder for this preprint (which was not certified by peer review) is the author/funder, who has granted medRxiv a license to display the preprint in It is made available under a CC-BY-NC-ND 4.0 International license .

533

534

535

536

537

538

539

540

541

542

543

544

545

546

547

548

549

550

551

552

553

554

555

556

53. Ejaredar M, Lee Y, Roberts DJ, Sauve R, Dewey D. Bisphenol A exposure and children's behavior: A systematic review. J Expo Sci Environ Epidemiol 2017 272. 2016 Mar 9;27(2):175-83.

54. Jeddi MZ, Janani L, Memari AH, Akhondzadeh S, yunesian M. The role of phthalate esters in autism development: A systematic review. Environ Res. 2016 Nov 1;151:493-504.

55. Zarean M, Keikha M, Feizi A, Kazemitabaee M, Kelishadi R. The role of exposure to phthalates in variations of anogenital distance: A systematic review and meta-analysis.

Environ Pollut. 2019 Apr 1;247:172-9.

56. Rochester JR. Bisphenol A and human health: A review of the literature. Reprod Toxicol. 2013 Dec 1;42:132-55.

57. Hauser R, Calafat AM. Phthalates and human health. Occup Environ Med. 2005 Nov $1 ; 62(11): 806-18$.

58. Wu M, Tu C, Liu G, Zhong H. Time to Safeguard the Future Generations from the Omnipresent Microplastics. Bull Environ Contam Toxicol [Internet]. 2021 Jul 5 [cited 2021 Aug 17]; Available from: https://doi.org/10.1007/s00128-021-03252-1

59. Velis CA, Cook E. Mismanagement of Plastic Waste through Open Burning with Emphasis on the Global South: A Systematic Review of Risks to Occupational and Public Health. Environ Sci Technol. 2021;55:7186-207.

60. Lebreton L, Andrady A. Future scenarios of global plastic waste generation and disposal. Palgrave Commun 2019 51. 2019 Jan 29;5(1):1-11.

61. Johannes HP, Kojima M, Iwasaki F, Edita EP. Applying the extended producer responsibility towards plastic waste in Asian developing countries for reducing marine plastic debris. Waste Manag Res J Int Solid Wastes Public Clean Assoc ISWA. 2021

May;39(5):690-702. 
medRxiv preprint doi: https://doi.org/10.1101/2022.02.10.22270706; this version posted February 10, 2022. The copyright holder for this preprint (which was not certified by peer review) is the author/funder, who has granted medRxiv a license to display the preprint in It is made available under a CC-BY-NC-ND 4.0 International license .

557

558

559

560

561

562

563

564

565

566

567

568

569

570

571

572

573

574

575

576

577

578

579

580

62. ECHA (European Chemicals Agency). Mapping exercise - Plastic additives initiative [Internet]. European Chemicals Agency. [cited 2020 Jul 21]. Available from:

https://echa.europa.eu/de/mapping-exercise-plastic-additives-initiative\#table

63. ECHA (European Chemicals Agency). Candidate list of substances of very high concern for authorisation [Internet]. European Chemicals Agency. 2021 [cited 2020 Jul 21].

Available from: https://echa.europa.eu/candidate-list-table

64. ECHA (European Chemicals Agency). Substances restricted under REACH

[Internet]. [cited 2020 Jul 21]. Available from: https://echa.europa.eu/de/substancesrestricted-under-reach

65. Stockholm Convention. Stockholm Convention on persistent organic pollutants (POPS) [Internet]. UN Environment Programme; 2019 [cited 2020 Jul 21]. Available from: http://chm.pops.int/TheConvention/Overview/TextoftheConvention/tabid/2232/Default.aspx

66. Stockholm Convention. POPRC recommendations for listing chemicals [Internet]. 2019 [cited 2020 Jul 21]. Available from:

http://chm.pops.int/Convention/POPsReviewCommittee/Chemicals/tabid/243/Default.aspx 67. Groh KJ, Backhaus T, Carney-Almroth B, Geueke B, Inostroza PA, Lennquist A, et al. Overview of known plastic packaging-associated chemicals and their hazards. Sci Total Environ. 2019 Jul;651:3253-68.

68. ATSDR (Agency for Toxic Substances and Disease Registry). ATSDR's Substance Priority List [Internet]. 2020 [cited 2020 Jul 16]. Available from:

https://www.atsdr.cdc.gov/spl/index.html

69. CROW (Chemical Retrieval on the Web). CROW Polymer Science [Internet]. CROW Polymer Science. 2021 [cited 2021 Apr 27]. Available from:

https://www.polymerdatabase.com/ 
medRxiv preprint doi: https://doi.org/10.1101/2022.02.10.22270706; this version posted February 10, 2022. The copyright holder for this preprint (which was not certified by peer review) is the author/funder, who has granted medRxiv a license to display the preprint in It is made available under a CC-BY-NC-ND 4.0 International license .

581 70. Wypych G. Handbook of Polymers [Internet]. Second edition. Toronto: ChemTec

582 Publishing; 2016. 706 p. Available from:

583 https://www.sciencedirect.com/science/article/pii/B9781895198928500021

584 71. Lithner D, Larsson A, Dave G. Environmental and health hazard ranking and

585 assessment of plastic polymers based on chemical composition. Sci Total Environ. 2011

586 Aug;409(18):3309-24.

587 72. Koltzenburg S, Maskos M, Nuyken O. Polymer Chemistry [Internet]. Berlin

588 Heidelberg: Springer-Verlag; 2017. Available from:

589 https://www.springer.com/gp/book/9783662492772

590 73. Ravve A. Principles of Polymer Chemistry [Internet]. 3rd ed. New York: Springer-

591 Verlag; 2012. Available from: https://www.springer.com/gp/book/9781461422112

592 74. Braun D, Cherdron H, Rehahn M, Ritter H, Voit B. Polymer Synthesis: Theory and

593 Practice: Fundamentals, Methods, Experiments [Internet]. 5th ed. Berlin Heidelberg:

594 Springer-Verlag; 2013. Available from: https://www.springer.com/gp/book/9783642289798

595 75. Salamone JC. Polymeric Materials Encyclopedia [Internet]. Vol. 9. London New

596 York: CRC Press; 1996. 554 p. Available from:

597 https://books.google.com.au/books?id=oYHJ-imh7rgC

598 76. World Health, Organization (WHO). International Classification of Diseases,

599 Eleventh Revision (ICD-11) [Internet]. 2019. Available from: https://icd.who.int/browse11.

600 Licensed under Creative Commons Attribution-NoDerivatives 3.0 IGO licence (CC BY-ND

6013.0 IGO).

602 77. Peters MDJ, Marnie C, Tricco AC, Pollock D, Munn Z, Alexander L, et al. Updated

603 methodological guidance for the conduct of scoping reviews. JBI Evid Synth. 2020 Oct

$604 \quad 1 ; 18(10): 2119-26$. 
medRxiv preprint doi: https://doi.org/10.1101/2022.02.10.22270706; this version posted February 10, 2022. The copyright holder for this preprint (which was not certified by peer review) is the author/funder, who has granted medRxiv a license to display the preprint in It is made available under a CC-BY-NC-ND 4.0 International license.

605 78. Tricco AC, Lillie E, Zarin W, O’Brien KK, Colquhoun H, Levac D, et al. PRISMA

606 Extension for Scoping Reviews (PRISMA-ScR): Checklist and Explanation.

607 Httpsdoiorg107326M18-0850. 2018 Sep 4;169(7):467-73.

608 79. Khalil H, Peters MDJ, Tricco AC, Pollock D, Alexander L, McInerney P, et al.

609 Conducting high quality scoping reviews-challenges and solutions. J Clin Epidemiol. 2021

610 Feb 1;130:156-60.

611 80. Venn M. Subject Guides: Systematic Reviews for Health: 8. Search Limits [Internet].

612 2020. Available from: https://utas.libguides.com/SystematicReviews/SearchLimits

613 81. Bramer W, Fowler S, Ket J, Otten R, Riphagen I. Animal studies exclusion - bmi-

614 online search blocks [Internet]. Biomedische Informatie. 2020. Available from:

615 https://blocks.bmi-online.nl/catalog/16

616 82. Tessier V. Human studies [Internet]. CHLA Canadian Health Libraries Association.

617 2019. Available from:

618 https://extranet.santecom.qc.ca/wiki/!biblio3s/doku.php?id=concepts:etudes-sur-les-humains 
medRxiv preprint doi: https://doi.org/10.1101/2022.02.10.22270706; this version posted February 10, 2022. The copyright holder for this preprint (which was not certified by peer review) is the author/funder, who has granted medRxiv a license to display the preprint in It is made available under a CC-BY-NC-ND 4.0 International license. 


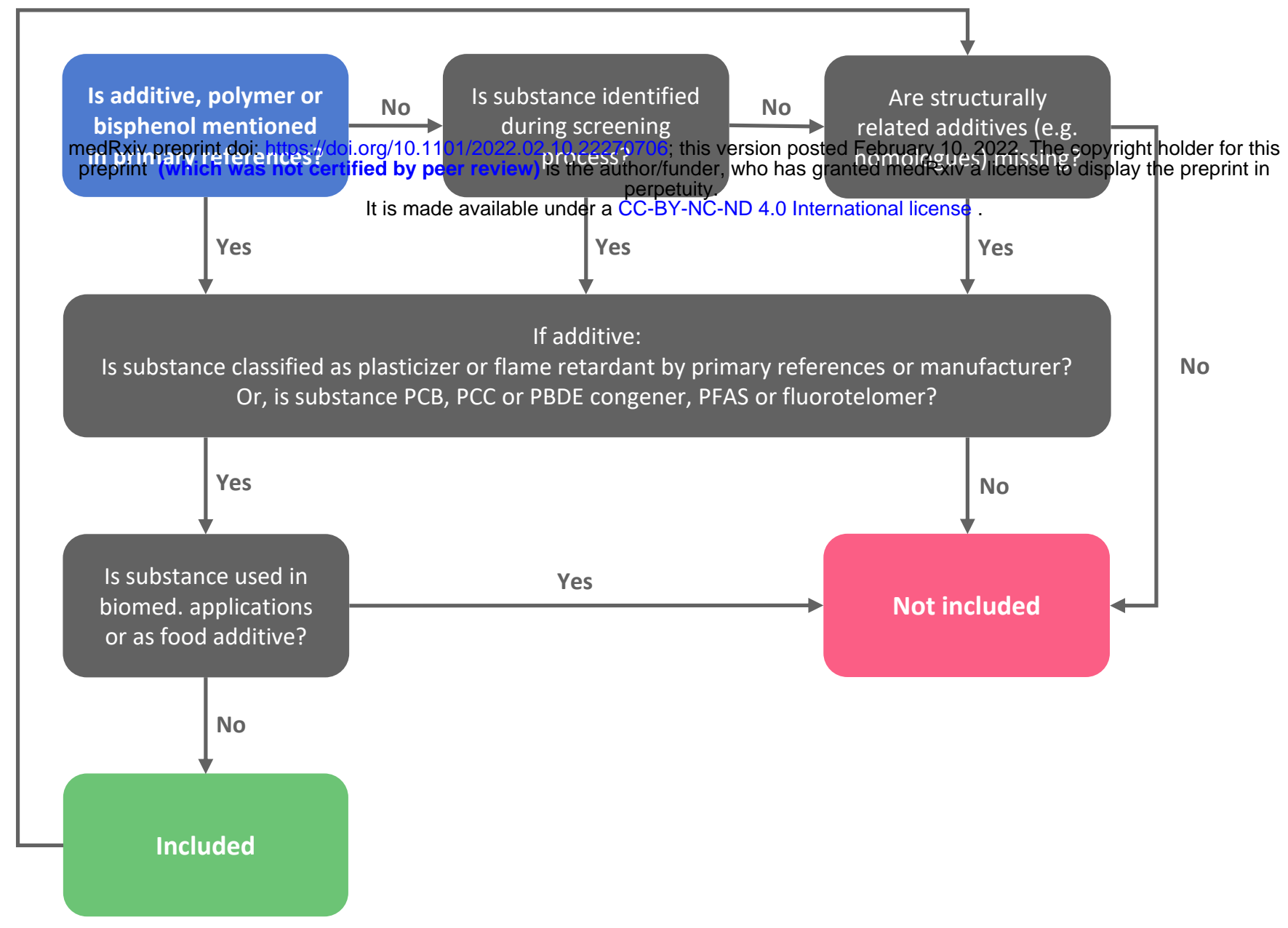


References identified through database searching

$(n=)$

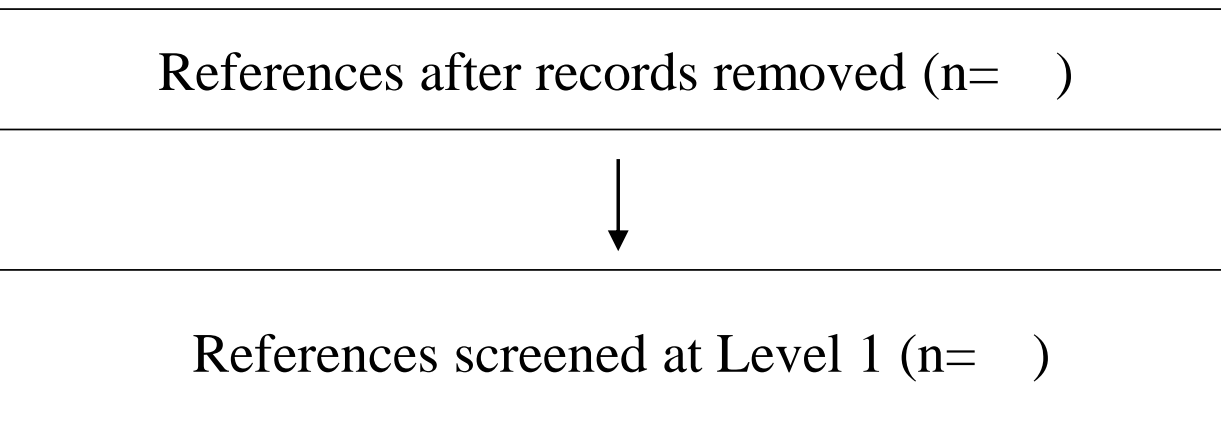

\section{$\longrightarrow \quad$ References excluded at Level $1(\mathrm{n}=\quad)$}

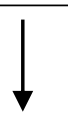

Full-text articles (Level 2) assessed for eligibility $(\mathrm{n}=)$

Full-text articles excluded $(\mathrm{n}=\quad)$

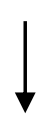

